\title{
GLL
}

00

\section{ASSESSMENT OF THE IMPACT OF SMALL BRIDGES ON THE DITCH CAPACITY OF THE DRAINAGE SYSTEM}

\author{
Bogusław Michalec, Stanisław Lubowicz
}

\section{Summary}

The objective of the present study was to determine the impact of two small bridges located within the main ' $R$ ' ditch of the Łączany drainage system on the capacity of the selected fragment of this ditch. A fragment of the ' $\mathrm{R}$ ' ditch was selected for the study, $311.7 \mathrm{~m}$ long, with two small bridges (bridge No. 1 at km $3+455$ and bridge No. 2 at $\mathrm{km} 3+365$ ) and 11 crosssections. Having conducted hydraulic calculations, the capacity of the selected fragment of the ditch was ascertained, assuming the base flow (reliable discharge) determined in the detailed design of the drainage system. The base flow, amounting to $9.77 \mathrm{~m}^{3} \cdot \mathrm{s}^{-1}$, was also used to determine water damming in the examined bridges in accordance with the Regulation by the Minister of Transport and Maritime Economy. As a result of geodetic measurements, changes in the shape of the cross-sections of the ditch and changes to the bottom slope within the tested segment of the ditch were found. It was established that under the conditions of proper maintenance of the ditch, its capacity is not lower than the base flow. However, if the maintenance is neglected, the area before bridge No. 1 will be flooded, which is the result of the lowered capacity of the ditch.

It was also found that the examined bridges did not contribute to the deterioration of the conditions of the base flow water through the ditch in the analysed fragment thereof.

\section{Keywords}

damming • small bridge $\bullet$ base flow (reliable discharge) $\bullet$ capacity $\bullet$ drainage system

\section{Introduction}

The primary purpose of melioration is to improve the productive capacity of soil through the implementation of technical and agrotechnical measures. As reported by Nyc and Pokładek [2004], drainage devices and systems should be properly used, among other things, for intensive agricultural production, as well as for improving the quality of the environment. The effects of melioration depend on the level of exploitation of melioration devices and systems, as well as the level of agricultural economy in these areas. Melioration systems serve not only to improve agricultural activity, but they also affect the basic elements of the natural environment, shaping the circulation of matter and 
resources, particularly water. Apart from the quantitative problem, i.e. water deficit, special attention is paid to the problem of water quality. This also applies to drained areas, and the problem of water quality in these areas is presented, among others, in the works by Kiryluk [2004], Nyc and Pokładek [2004], Grzywna [2010], Al-Omran et al. [2010], Zaman et al. [2018], Kaletova and Jurik [2018]. Furthermore, melioration systems play an important role in mitigating the effects of extreme hydrological phenomena (such as floods or droughts), and they can also counteract the negative effects of the damming of groundwater. The condition of the canals and ditches within drainage systems - treated as water devices in the light of the applicable regulations [Water Law 2017] - also largely depend on the factors of the water balance, including outflow, evaporation, and retention [Kaca et al. 2011]. An example of a melioration system, the task of which is to eliminate negative effects of groundwater damming as a result of accumulating the waters of the Vistula river with a water barrage in Łączany, is the Łączany drainage system. The Łączany barrage was built in the years 1954-1961 as one of the six barrages of the upper Vistula cascade [Lebienicki and Zielińska-Szczęsny 2006]. The constructed barrages changed the water conditions in the areas adjacent thereto, and so it had become necessary to protect the neighbouring areas against the negative effects of water damming. For this purpose, drainage systems were built in the adjacent areas. One of them is the Łączany barrage drainage system. This system has been subjected to systematic maintenance throughout its more than fifty years of operation. Temporary renovations and reconstructions have also been conducted. Some of the modernizations performed were carried out by unauthorized persons, namely, most often by the inhabitants of the protected area, causing deterioration of the conditions of water discharge by the system [Michalec et al. 2013]. Many years of use of the Łączany drainage system, despite maintenance works, resulted in a change in the geometry of the main ditch ' $R$ ' of the system as well as the side ditches. This had been caused by ditch slope landslides, and sediment accumulation at the bottom of the ditches, which in turn led to the reduction of local bottom gradients, and to reduced capacity of the ditches. The aim of the present study is to determine the impact of two small bridges on the main ' $R$ ' ditch of the Łączany drainage system on the capacity of the selected fragment of this ditch. An additional objective of our research is to verify the performed assessment of the capacity of the main ditch ' $\mathrm{R}$ ' based on detailed studies of the impact of small bridges on the capacity of the ditch. The performed tests made it possible to verify the capacity assessment of the main ditch ' $R$ '. The assessment of the capacity of the entire 8240-meter ditch ' $R$ ' was developed on the basis of the measurements performed at 70 cross-sections [Michalec 2018]. The aforementioned assessment took into account the impact of culverts but it did not take into account the impact of bridges, designed with a significant margin, due to their capacity. The results of the verification may be helpful in further works related to the analysis of the possibilities of improving the Łączany system, the main purpose of which is to eliminate the negative effects of the damming of groundwater; which is however also used in the flood protection of the drained area. 


\section{The studied object}

The Łączany water barrage is located at $\mathrm{km} 38+56$ of the Vistula River. As a result of damming, the Vistula water is gravity-fed to the Skawina Heat and Power Plant by means of an energy and navigation channel with a length of $15.5 \mathrm{~km}$, which is described in Figure 1 as the 'kanał Łączany' ('Łączany canal'). A detailed description of the drainage system can be found, among others, in the works of Michalec et al. [2013], Majerczyk and Michalec [2017] and Michalec [2018].

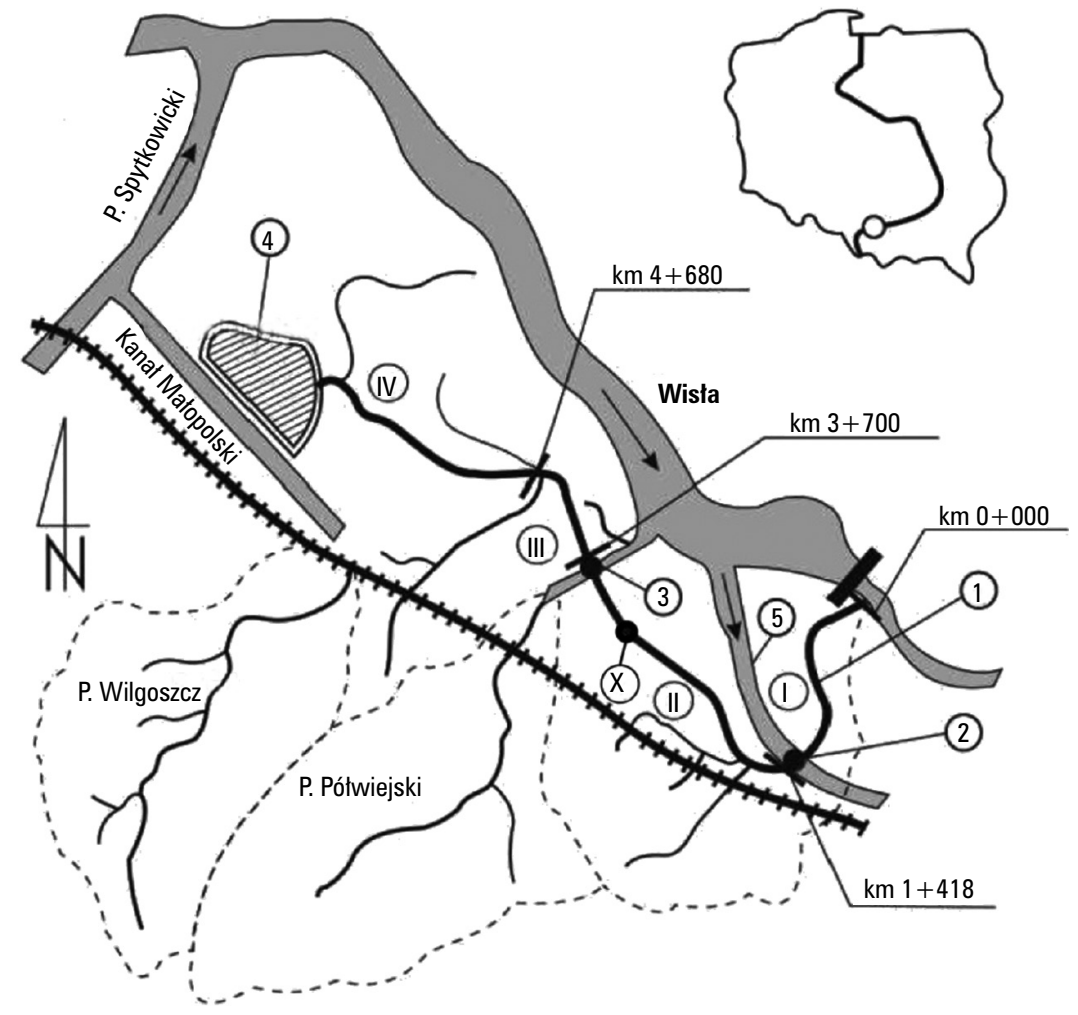

Fig. 1. Scheme of the Łączany drainage system: 1 - 'R'-ditch, 2 - siphon No 1, 3 - siphon No 2, 4 - Kasztelan pond, 5 - Łączany canal, I-IV - measurement cross-sections of the ditch, $\mathrm{X}$ - fragment of the ditch selected for research

The main element of the drainage system for the areas adjoining the Łączany barrage is the main ditch, marked with the symbol ' $R$ '. It carries water from the Kasztelan pond (symbol 4 in Figure 1) to the Vistula River to the lower site of the Łączany barrage (symbol km $0+000$ in Figure 1). The catchment area of the ' $\mathrm{R}$ ' ditch, which is the main element of the drainage system at the Lączany barrage, mostly consists of arable land, whereas in the lower parts of the catchment there are grass- 
lands and built-up areas of the villages of Łączany, Zarzecze, Zagroda, and Nowa Wieś [Budowa pompowni dla rowu R... 1975]. Due to the inflow of side ditches to the ' $\mathrm{R}$ ' ditch, and also due to the increase in the catchment area along the course of the ' $R$ ' ditch, the latter was divided into four segments (I, II, III and IV in Figure 1). A base flow was assumed in the project for each of the segments. The values of the base flow for each of the segments of the ' $\mathrm{R}$ ' ditch are presented in Table 1, and the locations of the cross-sections enclosing individual segments of this ditch are shown in Figure 1. Table 1 also lists the basic technical parameters of the segments of the ' $R$ ' ditch, presented in Michalec's work [2018].

Table 1. Reliable discharge (base flow) values $Q_{4}$ for several segments of the ' $R$ '-ditch [Michalec 2018]

\begin{tabular}{|c|c|c|c|c|}
\hline \multicolumn{2}{|c|}{ The segments of the ' $R$ '-ditch } & \multirow{2}{*}{$\begin{array}{l}\text { Discharge } \\
Q_{4}\left[\mathrm{~m}^{3} \cdot \mathrm{s}^{-1}\right]\end{array}$} & \multirow{2}{*}{$\begin{array}{l}\text { Width of bottom } \\
\qquad b[\mathrm{~m}]\end{array}$} & \multirow{2}{*}{$\begin{array}{c}\text { Depth of the ditch } \\
h[\mathrm{~m}]\end{array}$} \\
\hline No & {$[\mathrm{km}]$} & & & \\
\hline I & $0+000-1+418$ & 10.37 & 2.25 & 2.05 \\
\hline II & $1+418-3+700$ & 9.77 & 2.00 & 2.05 \\
\hline III & $3+700-4+680$ & 3.19 & 1.00 & 1.58 \\
\hline IV & $4+680-8+240$ & 1.28 & 0.50 & 1.16 \\
\hline
\end{tabular}

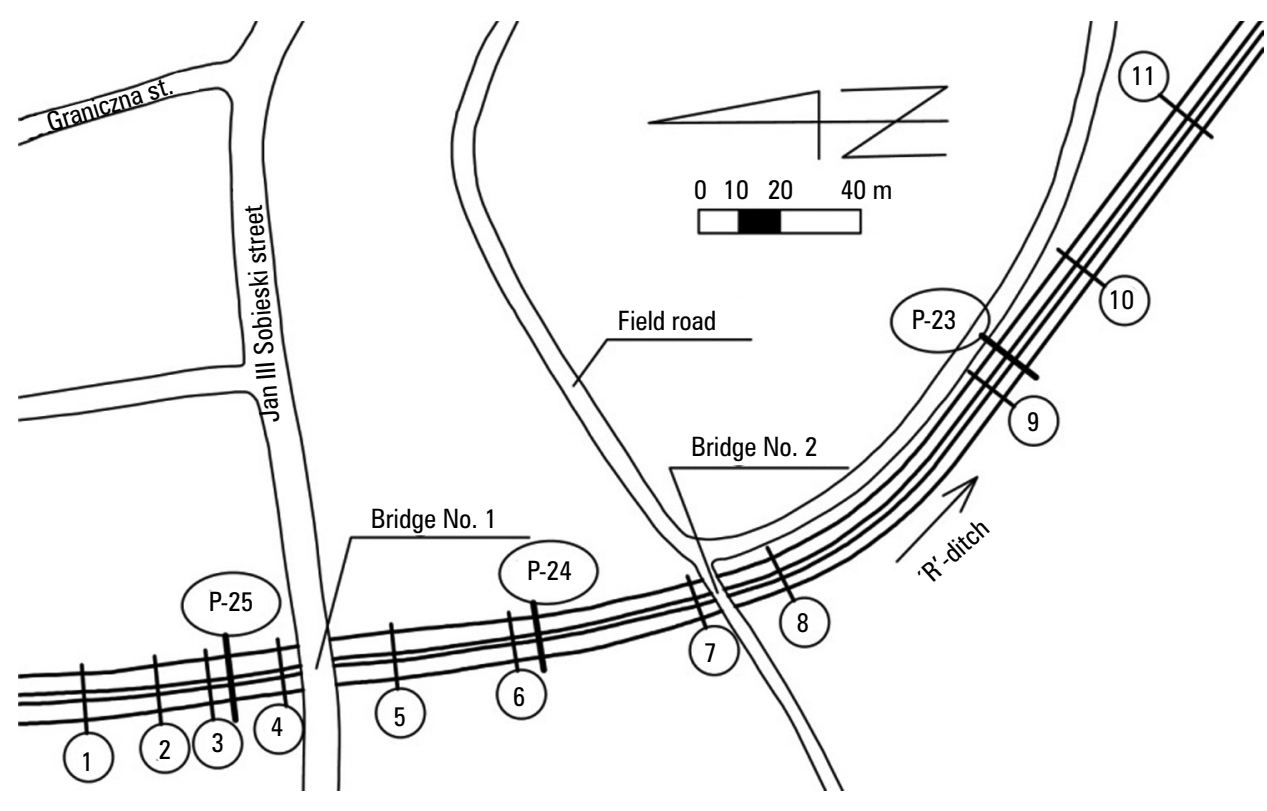

Fig. 2. The fragment of the ' $\mathrm{R}$ '-ditch in segment II selected for research 
Figure 1 also shows the fragment of the ' $\mathrm{R}$ ' ditch, $311.7 \mathrm{~m}$ long, that was selected for research, including two small bridges (bridge No. 1 at $\mathrm{km} 3+455$ and bridge No. 2 at $\mathrm{km} 3+365)$ and 11 cross-sections, determined during the research, as well as the P-23, P-24 and P-25 cross-sections, for which the capacity was determined as reported in the work of Michalec [2018]. The studied fragment of the ditch was located between the cross-sections at kilometre $3+203$ and $3+505$ (Fig. 2). This fragment is located on the second segment of the ' $\mathrm{R}$ ' ditch, for which, according to the project [Budowa pompowni dla rowu R... 1975], base flow (reliable discharge) is $9.77 \mathrm{~m}^{3} \cdot \mathrm{s}^{-1}$.

\section{Research methodology}

The field tests of the selected part of the 'R' ditch were carried out on November 20, 2019 and May 27, 2020. During the tests, geodetic measurements of the bottom slope and eleven cross-sections were carried out using the TOPCON AT-G7N leveller. Geodetic measurements of the bridge structures were also performed in order to determine their dimensions and skewness in relation to the channel axis. The locations of the crosssections used to calculate the bridge capacity were adopted in accordance with the Regulation by the Minister of Transport and Maritime Economy on technical conditions to be met by road engineering structures and their location [Rozporządzenie... 2000].

The capacity calculations were performed in two variants: in Variant I, corresponding to the good condition of the maintenance of the ditch channel, and in Variant II, corresponding to the poor condition of the maintenance of the ditch channel. Good condition refers to the conditions in which the slopes of the ditch are cleared, mowed and covered with low grass, while the bottom is covered with layers of clay. The poor condition of the ditch channel concerns the conditions of neglect of maintenance works, i.e. when the slopes were not cleared of tall grass or bushes. The maintenance condition of the ditch channel in Variant II was assumed as in Variant I.

Table 2. Established roughness coefficients

\begin{tabular}{|l|c|c|}
\hline \multirow{2}{*}{$\begin{array}{c}\text { The surface of the part } \\
\text { of the cross-section }\end{array}$} & \multicolumn{2}{|c|}{ Roughness coefficient $n\left[\mathrm{~m}^{-1 / 3} \cdot \mathrm{s}\right]$ acc. to Ven Te Chow } \\
\cline { 2 - 3 } & Variant I & Variant II \\
\hline Bottom of the ditch & 0.03 & 0.03 \\
\hline Ditch slope & 0.07 & 0.0225 \\
\hline Concrete walls of the bridge & 0.014 & 0.014 \\
\hline
\end{tabular}

Table 2 presents the established roughness coefficients according to Ven Te Chow [Książyński et al. 2000] for the adopted variants. These coefficients were used to calculate the velocity factor applying the Manning formula. The average water flow velocity was calculated using the Chezy formula for the given cross-section fill, and then the flow rate was calculated. 
The heights of water damming $(\Delta Z)$ across each of the examined bridges were calculated in accordance with the principles specified in the Regulation by the Minister of Transport and Maritime Economy [Rozporządzenie... 2000], using the following formula, corresponding to the scheme of a high-water bridge:

$$
\Delta Z=K \cdot \frac{\alpha \cdot v^{2}}{2 \cdot g}+\frac{\alpha_{0}\left(v_{0}^{2}-v_{s}^{2}\right)}{2 g}[\mathrm{~m}]
$$

where:

$v$ - mean water velocity under the bridge in clear cross-section, limited by the elevation of the water table at the given base flow $\left[\mathrm{m} \cdot \mathrm{s}^{-1}\right]$,

$v_{0}$ - mean velocity of the base flow in the undeveloped cross-section $\left[\mathrm{m} \cdot \mathrm{s}^{-1}\right]$,

$v_{s}$ - mean velocity of the base flow in the cross-section above the bridge after damming $\left[\mathrm{m} \cdot \mathrm{s}^{-1}\right]$,

$\alpha_{0}$ - Saint-Venant coefficient for the cross-section before the bridge (adopted: for a compact cross-section $\alpha_{0}=1,2[-]$,

$\alpha$ - Saint-Venant coefficient for the cross-section under the bridge [-],

$K-$ loss coefficient [-].

The Saint-Venant coefficient for the cross-section under the bridge $(\alpha)$ is calculated taking into account the effect of narrowing of the watercourse by the abutments of the bridge (influence of lateral contraction) using the formula:

$$
\alpha=1+M \cdot\left(\alpha_{0}-1\right),[-]
$$

wherein:

$\mathrm{M}$ - lateral contraction coefficient which is the ratio of the flow $\left(Q_{s}\right)$ in the part of the undeveloped channel corresponding to the gross bridge cross-section area and the base flow $\left(Q_{m}\right)$.

The flow $\left(Q_{s}\right)$ is calculated from the formula:

$$
Q_{s}=F_{s} \cdot v_{m},\left[\mathrm{~m}^{3} \cdot \mathrm{s}^{-1}\right]
$$

where:

$F_{s}$ - cross-sectional area of the bridge clearance at the flow $Q_{m},\left[\mathrm{~m}^{2}\right]$,

$v_{m}$ - water velocity in the cross-section above the bridge, $\left[\mathrm{m} \cdot \mathrm{s}^{-1}\right]$.

The loss factor $(K)$ is the sum of four components, i.e. the basic loss factor depending on the degree of narrowing of the watercourse by abutments and their shape $\left(K_{0}\right)$, the correction taking into account the impact of the abutments $\left(\Delta K_{f}\right)$, the correction taking into account the asymmetry of the bridge's clearance location in relation to the floodplain $\left(\Delta K_{e}\right)$, and the correction taking into account the impact of the oblique position of the bridge in relation to the watercourse axis $\left(\Delta K_{\varphi}\right)$.

In the conditions of flooding the inlet and outlet of the bridge span, the water damming heights $(\Delta Z)$ for each of the examined bridges were calculated accord- 
ing to the scheme corresponding to bridges with siphonic flow (pressure flow) in accordance with the Regulation by the Minister of Transport and Maritime Economy [Rozporządzenie... 2000]:

$$
Q=C \cdot A \cdot \sqrt{2 \cdot g \cdot H},\left[m^{3} \cdot s^{-1}\right]
$$

where:

$C$ - flow coefficient of the flooded inlet (usually $C=0.8$ is assumed) [-],

$H$ - difference in heights of the water stream energy line in the cross-section above the bridge, and the water table past the structure $[\mathrm{m}]$,

$A$ - flow area in the bridge cross-section $\left[\mathrm{m}^{2}\right]$.

\section{Results}

Based on the results of geodetic measurements, cross-sections were developed, the parameters of which, such as the slope inclination module and the width of the ditch bottom, differ significantly from the parameters adopted in the project. Figure 3 shows an example of the cross-section 9-9, the shape of which differs the most from the design assumptions.

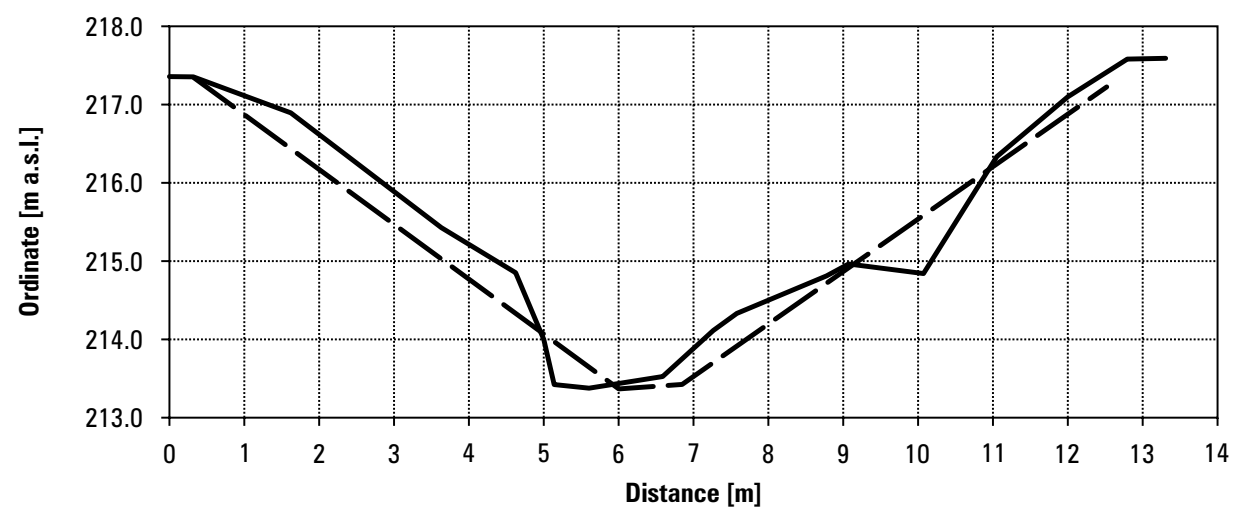

Fig. 3. Cross-section 9-9 according to measurements (solid line) and according to the design (dashed line)

The area of this cross-section, determined for the crest of the slopes according to the design, was $26.61 \mathrm{~m}^{2}$, while the area calculated on the basis of measurements is 25.67 $\mathrm{m}^{2}$, which means a reduction in the cross-sectional area by $3.5 \%$. The leveling line was tied to the bridge benchmarks. The leveling line was also tied to the fixed, concrete, structural elements of the bridges.

The determined skewness of the bridges, as the value of the angle between the axis of the bridge road and the axis of the channel on the upper side of the water, amounts to: $90.0^{\circ}$ for bridge No. 1 , and $74.7^{\circ}$ for bridge No. 2 (Fig. 4). The specific dimensions 
of the bridge spans in their clearance are as follows: the width of the span of bridge No. 1 is $3.53 \mathrm{~m}$, and the width of bridge No. 2 is $3.18 \mathrm{~m}$. The clear height of bridge No. 1 is $2.58 \mathrm{~m}$, and the corresponding figure for bridge No. 2 is $3.04 \mathrm{~m}$. The tested bridges are characterized not only by the different dimensions of their spans, but also by the thickness of the beams of the span, which is $1.12 \mathrm{~m}$ in bridge No. 1 , and $1.30 \mathrm{~m}$ in bridge No. 2 [Lubowicz 2020].

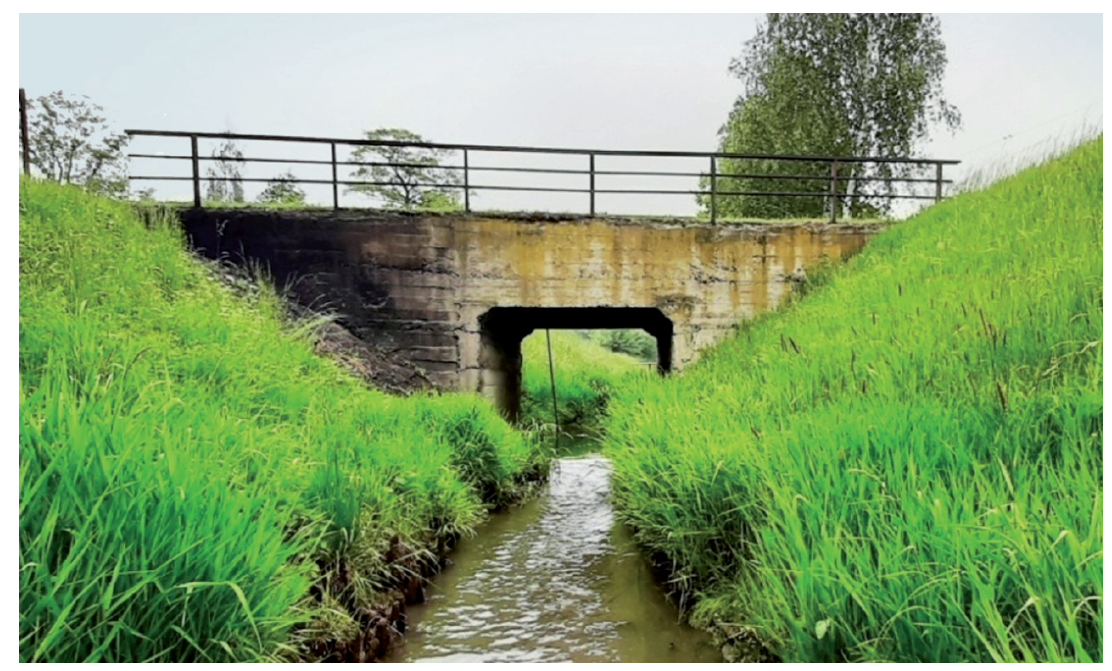

Fot. B. Michalec

Fig. 4. Photo of the bridge No. 2 - view from the upper water

The calculated slopes of the bottom between the individual cross-sections turned out to be significantly different from the slope designed for the studied fragment of the ditch (Fig. 5). According to the design, the slope of the bottom of the studied fragment of the ditch was $0.5 \%$. In Figure 5, a dashed line marks the slope of the ditch bottom, as it should be according to the design. Based on the results of the measurements, it turned out that the bottom of the ditch was lowered before both bridges, and that past bridge No. 2, as a result, this contributed to the formation of slopes, the value of which is negative. This concerns segments between cross-section 4 and bridge No. 1, crosssection 6 and bridge No. 2, and also between cross-sections 6 and 11 (Fig. 5). Due to the trims and back slopes, the hydraulic calculations were made for the assumed leveled slopes, calculated for the ditch segments between cross-section 1 and $U$ of bridge No. 1 (upstream of bridge No. 1), between cross-section D of bridge No. 1 (downstream of bridge No. 1), and $\mathrm{U}$ of bridge No. 2 (upstream of bridge No. 2) and between crosssection D of bridge No. 2 (downstream of bridge No. 2) and cross-section 11. The gradients of these slopes are respectively: $0.17,0.59$, and $0.64 \%$. The average gradient of the tested fragment, calculated for the cross-sections $1-11$, is $0.51 \%$ and is almost equal to the gradient adopted in the design. 


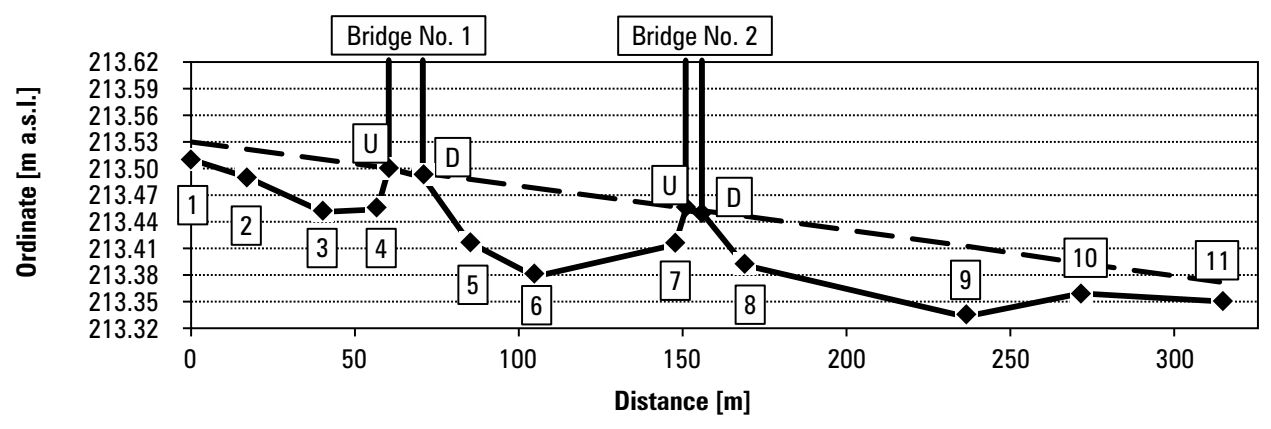

Fig. 5. Longitudinal profile of the investigated fragment of the ditch - points from 1 to 11 indicate the ordinates of the bottom in selected cross-sections, points $U$ and $\mathrm{D}$ are the ordinates of the bottom in the bridges, whereas the dashed line marks the bottom line with a slope in the design

Based on the results of geodetic measurements, the filling in each of the crosssections was calculated at the flow that was reliable (base flow) for both adopted variants. At this stage of capacity calculations, the impact of the bridges on the flow conditions of the reliable discharge (base flow) was not taken into account. Table 3 contains the values of filling for the base flow, amounting to $9.77 \mathrm{~m}^{3} \cdot \mathrm{s}^{-1}$, as well as the value of the reserve, which is the difference between the lowest ditch crest elevation and the water elevation of the base flow. In the case of conveyance in a given cross-section lower than the base flow rate, the symbol '-' was inserted in Table 3.

Table 3. Conveyance in cross-sections of the ' $\mathrm{R}$ '-ditch determined for the reliable discharge (base flow)

\begin{tabular}{|c|c|c|c|c|c|}
\hline \multirow{2}{*}{$\begin{array}{c}\text { Cross- } \\
\text { section }\end{array}$} & \multirow{2}{*}{$\begin{array}{c}\text { Kilometer } \\
\text { of the ditch } \\
{[\mathrm{km}]}\end{array}$} & \multicolumn{2}{|c|}{ Variant I } & \multicolumn{2}{c|}{ Variant II } \\
\cline { 3 - 6 } & $h[\mathrm{~m}]$ & $\begin{array}{c}\text { Water depth } \\
{[\mathrm{m}]}\end{array}$ & $\begin{array}{c}\text { Reserve } \\
h[\mathrm{~m}]\end{array}$ & $\begin{array}{c}\text { Weserve } \\
{[\mathrm{m}]}\end{array}$ \\
\hline 1 & $3+505$ & 2.11 & 1.02 & 3.07 & 0.06 \\
\hline 2 & $3+488$ & 2.04 & 1.05 & 3.98 & 0.11 \\
\hline 3 & $3+475$ & 2.16 & 0.99 & - & - \\
\hline $\mathrm{P}-25$ & $3+741$ & 3.02 & 0.78 & - & - \\
\hline 4 & $3+459$ & 2.06 & 1.08 & - & - \\
\hline 5 & $3+431$ & 2.04 & 1.24 & 3.01 & 0.27 \\
\hline 6 & $3+411$ & 2.61 & 1.11 & - & - \\
\hline P-24 & $3+407$ & 2.68 & 1.13 & 3.55 & 0.26 \\
\hline
\end{tabular}


Table 3. cont.

\begin{tabular}{|c|c|c|c|c|c|}
\hline \multirow{2}{*}{$\begin{array}{c}\text { Cross- } \\
\text { section }\end{array}$} & \multirow{2}{*}{$\begin{array}{c}\text { Kilometer } \\
\text { of the ditch } \\
{[\mathrm{km}]}\end{array}$} & \multicolumn{2}{|c|}{ Variant I } & \multicolumn{2}{c|}{ Variant II } \\
\cline { 3 - 6 } & $h[\mathrm{~m}]$ & $\begin{array}{c}\text { Water depth } \\
{[\mathrm{m}]}\end{array}$ & $\begin{array}{c}\text { Reserve } \\
h[\mathrm{~m}]\end{array}$ & $\begin{array}{c}\text { Water depth } \\
{[\mathrm{m}]}\end{array}$ \\
\hline 7 & $3+368$ & 2.68 & 1.04 & 3.39 & 0.33 \\
\hline 8 & $3+347$ & 2.50 & 1.45 & 3.66 & 0.29 \\
\hline 9 & $3+280$ & 2.51 & 1.49 & 3.59 & 0.41 \\
\hline $\mathrm{P}-23$ & $3+274$ & 2.46 & 1.29 & 2.94 & 0.81 \\
\hline 10 & $3+245$ & 2.48 & 1.44 & 3.52 & 0.40 \\
\hline 11 & $3+203$ & 2.49 & 1.40 & 3.47 & 0.42 \\
\hline
\end{tabular}

In the cross-sections before the bridge No. 1, in conditions of good maintenance of the channel (Variant I), the reliable discharge (base flow) is contained within the bed of the ditch, while in the case of allowing the slopes to become overgrown with excessive vegetation (Variant II), overflow occurs - not only before the bridge No.1 (cross-sections 3 and 4 - Table 3), but also past the bridge (cross-section 6 - Table 3 ). Also in the analysis of the capacity of the ' $R$ ' ditch, presented in the study by Michalec [2018], it was demonstrated that the cross-section of the ditch before the bridge has a lower capacity than the base flow (cross-section P-25 - Table 3).

Table 4 presents the calculations results of the damming in bridge No. 1. In Variant I, the level of the water table for the base flow in the cross-sections before and after the bridge remains below the beam of the bridge's span. Thus, the calculations of water damming were made as per the high-water bridge, using the formula (1). The water damming height $(\Delta \mathrm{Z})$ is $0.10 \mathrm{~m}$ (Table 4 ) and it will not cause the base flow to overflow from the bed, as the reserve value (R, Table 3 ) in the cross-sections before bridge No. 1 ranges from 0.99 to $1.08 \mathrm{~m}$.

On the other hand, in Variant II, due to the flow capacity of cross-section 4 lower than the relevant flow, the bankfull discharge was assumed to be $9.57 \mathrm{~m}^{3} \cdot \mathrm{s}^{-1}$ for the calculation of damming in the clearance of bridge No. 1. This flow causes flooding of the bridge span from the upper water side, and also from the lower water side. In crosssection 5, the filling is $2.94 \mathrm{~m}$, and the clear height of bridge No. 1 is $2.58 \mathrm{~m}$. Taking into account also the difference in the ordinates of the bottom in the bridge cross-section and cross-section 5, which is $9 \mathrm{~cm}$, flooding of the beam of the bridge span from the bottom water side is $27 \mathrm{~cm}$. Calculation of damming in bridge No. 1 in Variant II was performed using the scheme of the bridge with siphonic flow (pressure flow). Taking into account the height of the flow velocity line in the cross-section before the bridge, amounting to $0.014 \mathrm{~m}$, the difference in the elevation of water stream energy line in the cross-section upstream from the bridge versus the water table past the structure was calculated, i.e. $H$ in formula (4). For the calculated value of $H=0.12 \mathrm{~m}$, the flow rate in 
the span of bridge No. 1 is $11.35 \mathrm{~m}^{3} \cdot \mathrm{s}^{-1}$. This expenditure is higher than the bankfull discharge, amounting to $9.57 \mathrm{~m}^{3} \cdot \mathrm{s}^{-1}$, for which the calculations were performed. This means that bridge No. 1 has no impact on the damming of the bankfull flow in the neglected condition of the ditch channel.

Table 4. The base flow damming at the investigated bridges for Variant I calculated by the formula (1)

\begin{tabular}{|c|c|c|}
\hline Parameter & Bridge No. 1 & Bridge No. 2 \\
\hline$v\left[\mathrm{~m} \cdot \mathrm{s}^{-1}\right]$ & 1.52 & 5.16 \\
\hline$Q_{s}\left[\mathrm{~m}^{3} \cdot \mathrm{s}^{-1}\right]$ & 6.17 & 0.53 \\
\hline$M[-]$ & 0.632 & 0.106 \\
\hline$A[-]$ & 0.126 & 1.55 \\
\hline$K_{0}[-]$ & 0.72 & 0 \\
\hline$\Delta K_{f}[-]$ & 0 & 0 \\
\hline$\Delta K_{e}[-]$ & 0 & -0.09 \\
\hline$\Delta K_{\varphi}[-]$ & 0 & 1.46 \\
\hline$K[-]$ & 0.72 & 1.16 \\
\hline$v_{0}\left[\mathrm{~m} \cdot \mathrm{s}^{-1}\right]$ & 0.97 & 0.45 \\
\hline$v_{s}\left[\mathrm{~m} \cdot \mathrm{s}^{-1}\right]$ & 0.92 & 0.20 \\
\hline$\Delta Z[\mathrm{~m}]$ & 0.10 & \\
\hline
\end{tabular}

The water damming height $(\Delta Z)$ at bridge No. 2 in Variant II is $0.20 \mathrm{~m}$. It was calculated for the water table level of the base flow for the hydraulic conditions corresponding to the scheme for a high-water bridge. The calculated height of water damming $(\Delta Z)$, amounting to $0.20 \mathrm{~m}$, will not cause a base flow to overflow from the bed, as the reserve value (R, Table 3) in the cross-sections before bridge No. 2 ranges from 1.11 to $1.24 \mathrm{~m}$.

In Variant II, in bridge No. 2, its span will be flooded, because the base flow water table in the cross-section of the bridge, without damming, is $31 \mathrm{~cm}$ above the lower edge of the span beam. For this reason, the damming of base flow water in this bridge was calculated according to the scheme for the bridge with siphonic flow (pressure flow). Taking into account the height of the velocity line in the cross-section before the bridge, which is $0.014 \mathrm{~m}$, the calculated difference between the elevation of the water stream energy line in the cross-section upstream from the bridge (cross-section 7) and the water table past the structure, according to formula (4), amounts to $H=0.14 \mathrm{~m}$. Calculated for this value of $H$, the flow rate of the bridge span is $14.27 \mathrm{~m}^{3} \cdot \mathrm{s}^{-1}$ and is therefore much greater than the base flow, which means that the base flow is not 
dammed by this bridge in the neglected condition of the channel. In the cross-sections between the two bridges, i.e. in cross-sections 5 and 7 , the reserve value $(R)$ will not change, amounting to 27 and $33 \mathrm{~cm}$, respectively. In cross-section 6 , however, the flow does not fit in the channel bed due to the lowering of its crest.

\section{Conclusions}

The results of the verification constitute an example demonstrating the need for a more detailed diagnosis of the technical condition of the ditches making up the drainage systems. They also point to the need to perform additional measurements and analyses, including taking into account all engineering structures that may affect the capacity of the system. The pre-determined assessment of the capacity of the studied fragment of the ditch based on the analysis of three cross-sections has been confirmed by detailed studies, the results of which are presented in this paper. In the case of the studied bridges, no negative impact of the base flow damming was found, either in the conditions of good maintenance of the ditch channel (Variant I) or in the conditions of neglected maintenance works. Despite this, it was found that allowing the ditch slopes to become overgrown with excessive vegetation leads to an increase in water flow resistance and, in the case of base flow, causes the adjacent areas to be flooded. As reported by Nyc and Pokładek [2004], proper maintenance of watercourses (meaning their timely maintenance or repair) not only guarantees the necessary hydraulic capacity and the efficiency of the drainage system, but it also protects the bed of the watercourse against the accumulation of undesirable minerals in the muddy bottom, and the effects of putrefactive processes taking place in plants that have not been removed in a timely manner. Both the putrefactive processes and the inflow of polluted waters from drained areas may contribute to the deterioration of the condition of water.

According to Walczak et al. (2015), neglected ditches, which show many years of neglect in terms of lack of regular maintenance, reduce their capacity to about $80 \%$. According to the adopted assumptions, the calculated reduction in the capacity of the studied fragment of the ' $R$ ' ditch turned out to be lower than the value given by Walczak et al. [2015], as it was $38-44 \%$.

The underfunding of the administrators of the drainage systems, and in the case of the analysed facility at Łączany drainage system, contributes to the reduction of the scope of ditch maintenance works. As a result, the works consisting in cutting down the vegetation are performed once a year at the end of the growing season, which means that during torrential rains in the summer there is a risk of flooding the drained areas.

As a result of over fifty years of operation, despite the maintenance works on the main ditch 'R', significant changes in the geometry of the ditch cross-section occurred, in the form of local slope slides, which had an impact on reducing the cross-sectional area of the ditch.

The two studied bridges located within the selected segment of the ditch cause the damming of the base flow, however, this damming does not cause the water to overflow from the channel under the conditions of good maintenance. The water table 
system of the base flow in the profile of the examined bridges corresponds to that of the high-water bridge. In the event of neglecting maintenance works, as a result of which high vegetation is not removed, the adjacent areas located before the bridge No. 1 are flooded due to the limited capacity of the ' $R$ ' ditch. In the event of neglect of maintenance works, the water table of the base flow is raised, causing the inlet and outlet of both tested bridges to flood, however, in the conditions of siphonic flow (pressure flow) through these bridges, this flow will not accumulate.

\section{References}

Al-Omran A.M., Al-Harbi A.R., Wahb-Allah M.A., Nadeem M., Al-Eter A. 2010. Impact of irrigation water quality, irrigation systems, irrigation rates and soil amendments on tomato production in sandy calcareous soil. Turkish Journal of Agriculture and Forestry, 34(1), 59-73.

Budowa pompowni dla rowu R - Łączany. Ekspertyza. 1975. Biuro Projektów Wodnych Melioracji w Krakowie. Maszynopis.

Grzywna A. 2010. Jakość wody w zmeliorowanej dolinie rzecznej w latach 2004-2006. Infrastruktura i Ekologia Terenów Wiejskich, 14, 99-107.

Kaca E., Drabiński A., Ostrowski K., Pierzgalski E., Szafrański Cz. 2011. Gospodarowanie wodą w sektorze rolno-żywnościowym i obszarach wiejskich w warunkach nowych wyzwań i ograniczeń. Polish Journal of Agronomy, 7, 14-21.

Kaletová T., Jurík L. 2018. Quality of water required for irrigation. Water Resources in Slovakia, Part I, 97-113.

Kiryluk A. 2004. Wpływ nawożenia mineralnego i roślinności na jakość wód gruntowych w siedlisku łąk pobagiennych. Annales UMCS, sec. E, 59, 761-767.

Książyński K., Jeż P., Gręplowska Z. 2000. Tablice do obliczeń hydraulicznych. Wyd. PK, Kraków.

Lebienicki P., Zielińska-Szczęsny B. 2006. Stopień wodny Dąbie po 40 latach eksploatacji. Gospodarka Wodna, 12, 470-478.

Lubowicz S. 2020. Ocena wpływu mostów na warunki hydrauliczne przepływu wód wezbraniowych w systemie odwadniającym stopnia wodnego Łączany. Praca magisterska, Katedra Inżynierii Wodnej i Geotechniki, Uniwersytet Rolniczy w Krakowie, maszynopis.

Majerczyk A., Michalec B. 2017. Oddziaływanie przepustów na warunki hydrauliczne przepływu wody w głównym rowie systemu odwadniającego stopnia wodnego Łączany. Przegląd Naukowy - Inżynieria i Kształtowanie Środowiska, 26(1), 28-37.

Michalec B. 2018. Ocena przepustowości rowu głównego R systemu odwadniającego Łączany. Infrastruktura i Ekologia Terenów Wiejskich, III/1, 771-785.

Michalec B., Wałęga A., Cupak A. 2013. Retencja zbiornikowa w ochronie przeciwpowodziowej terenów systemu odwadniającego stopnia wodnego Łączany na Wiśle. Infrastruktura i Ekologia Terenów Wiejskich, 3/IV, 177-190.

Nyc K., Pokładek R. 2004. Rola małej retencji w kształtowaniu ilości i jakości wód. Zeszyty Naukowe AR we Wrocławiu, 502, 343-352.

Rozporządzenie Ministra Transportu i Gospodarki Morskiej z dnia 30 maja 2000 r. w sprawie warunków technicznych, jakim powinny odpowiadać drogowe obiekty inżynierskie i ich usytuowanie. Dz.U. z 2000 r. Nr 63, poz. 735.

Ustawa z dnia 20 lipca 2017 r. - Prawo wodne, Dz.U. z 2017 r., poz. 1566.

Walczak N., Hämmerling M., Bykowski J., Walczak Z. 2015. Ekonomiczne i hydrauliczne kryteria utrzymania dobrego stanu rowów melioracyjnych. Journal of Agribusiness and Rural Development, 1(35), 137-146. 
Zaman M., Shahid S.A., Heng L. 2018. Irrigation Water Quality. In: Guideline for Salinity Assessment, Mitigation and Adaptation Using Nuclear and Related Techniques. Springer, Cham. https://doi.org/10.1007/978-3-319-96190-3_5.

Prof. dr hab. inż. Bogusław Michalec Katedra Inżynierii Wodnej i Geotechniki Uniwersytet Rolniczy w Krakowie e-mail: rmmichbo@cyf-kr.edu.pl ORCID: 0000-0002-0402-3416

Mgr inż. Stanisław Lubowicz Dyplomant w Katedrze Inżynierii Wodnej i Geotechniki Uniwersytet Rolniczy w Krakowie e-mail: slubowicz@gmail.com 